\title{
DIFFERENT APPROACHES TO THE EBIT CON- STRUCTION AND THEIR IMPACT ON CORPO- RATE FINANCIAL PERFORMANCE BASED ON THE RETURN ON ASSETS: SOME EVIDENCE FROM CZECH TOP100 COMPANIES
}

- Jiř̀ Strouhal, Petra Štamfestová, Aleksandr Ključnikov, Zuzana Vincúrová

\section{Abstract}

The paper discusses ways of measuring the financial performance of businesses. The aim is to determine to what extent the form of profit calculation influences value of return on assets (hereinafter referred to as ' $R O A$ '), which is frequently used as an indicator for measuring financial performance. The theoretical part is focused on the comparative analysis of accounting data based on Czech practices and IFRS with the in-depth focus on interest charges and reporting requirements. There is discussed the topic of objective and subjective measurement of financial performance. In the practical part, $\mathrm{ROA}$ is calculated using a profit in two forms of its construction. There are evaluated TOP 100 Czech companies in order to assess the differences in the final values of the tested indicator. The results are linked to the capital structure of the analysed companies and prove that the level of indebtedness influences the difference in the ROA calculations when different kinds of profit are used. In the case of the companies with higher indebtedness, it is more appropriate to compare the ROA indicators based on the nominator containing earnings before interest and taxes. It shall be concluded that this is a pioneer study of this topic in the Czech Republic and probably also in the CEE region.

Keywords: EBIT, return on assets, TOP100, Czech Republic, financial performance, financial reporting JEL Classification: M41, G30

\section{INTRODUCTION}

Business corporations' level of financial performance is used to assess their success or failure and the level of fulfilling the corporate objectives set. The performance increases only if the corporation is able to fulfil the target values set. The performance improvement is without any doubt the ultimate goal of management and planning at all levels of control. The performance is always relative and, therefore, the individual measuring of financial performance has a lower information value of measured data when appropriate comparison is not applied. The achieved values of financial indicators can be compared with the results from previous periods. However, they should be especially compared to competitors or industry average results. The benchmark to the past is possible but the benchmarking to the competitors is crucial when the corporation wants to create a long-term competitive advantage. It often happens that the corporate financial performance improves but the performance is inadequate in comparison with other corporations' performance. 
The essence of evaluating performance is to define the indicators which are relevant to the evaluators and to compare their values with the values achieved by the competitors chosen, in the industry or in the past. There is a need of consistency regarding a financial indicators construction selected for the benchmark. The consistency or inconsistency would influence the evaluation quality and also the subsequent decision making process about possible action steps leading to the performance improvement. Individual elements of financial performance can be measured not only by different indicators but these indicators are often used in several forms and they can also be constructed differently.

The measurement and evaluation of financial performance is reduced to the assessment of profitability in many researches because it is one of the most important elements of financial performance. The other elements are liquidity, activity and indebtedness. The most used indicators of profitability are ROE (net income/equity) measuring the return for owners, ROA (EBIT/assets) measuring the return of total assets and profit margin (net income/sales). This paper is focused on return on assets (ROA) and ways of its construction. The assessment of profitability could be often distorted because of different construction approaches. It is caused by more ways to calculate the profit used in the nominator of the indicator discussed. It is possible to meet the profitability construction of ROA based on net income, although the main aim of the selected indicator is better fulfilled with the profit independent on capital structure and the level of taxation. The production power of the assets is not influenced by the territory on which the assets are used and it is also not possible to increase the production power by the way of financing. Therefore, there is a consensus that return on assets should be abstracted from the level of taxation and forms of financing.

The paper's aim is to assess if and how the profit construction can influence the achieved value of corporation production power measured by return on assets which belongs to the classical ratios measuring the financial performance. The analysis will be conducted in the following way. First, the literature review will be done and it will also contain an insight into the applicable accounting legal rules and principles in the Czech Republic. Further, the research methodology will be introduced and the chosen sample will be analysed according to the influence of different profit approaches as well as capital structure on the indicator ROA. Last but not least, the discussion of the results will be carried out. The part of conclusion will contain final recommendations and limitations of the current phase of research.

\section{LITERATURE REVIEW}

Return on assets (ROA) is often used for measuring the financial performance in different kinds of research studies. The financial indicators including ROA can be measured both objectively based on the data derived from financial statements and subjectively using scales. Data are influenced by the accounting standards. (Klečka \& Čamská, 2015) The figure of precise ROA computation informs about the amount of profit generated by one currency unit of property (crown, dollar, euro, etc.) in the analysed accounting period. It is evident that this criterion is maximizing. Models predicting financial distress are based on the following ideas. According to their financial performance, it is possible to distinguish companies with a high and low probabil- 
ity of bankruptcy. The models included in the paper use the financial data derived from financial statements for prediction. Statistical methods as the discriminant analysis and logistic regression were originally used for the models' construction. (Čamská, 2016, pp. 354)

ROA is an indicator of how profitable a company is relative to its total assets. ROA gives a manager, investor, or analyst an idea how efficient a company's management is at using its assets to generate earnings. (Růčková, 2011) The direction and intensity of action factors that affect ROA may therefore always be different. (Kotulič, 2014) In basic terms, ROA tells you what earnings were generated from invested capital. ROA for public companies can vary substantially and will be highly dependent on the industry. This is why, when using ROA as a comparative measure, it is best to compare it to a company's previous ROA numbers or to a similar company's ROA. The company's total assets are the sum of its total liabilities and shareholder's equity. Both of these types of financing are used to fund the operations of the company. Since a company's assets are either funded by debt or equity, some analysts and investors disregard the cost of acquiring the asset by adding back interest expense in the formula for ROA. The impact of taking more debt is negated by adding back the cost of borrowing to the net income, and using the average assets in a given period as the denominator. Interest expense is added because the net income amount on the income statement excludes interest expense. ROA refers to the productive power and gives the proportion of profit with the total assets invested in the business, regardless of the way of financing. It is important for an enterprise to effectively use its property base. There are several variants to calculate it. The most complex indicator is the form of EBIT (profit before interest and tax) in the numerator and is particularly useful when changing the rate of tax on profit over time, the structure of financing or comparing companies with different financing structures. The possibility of EBIT $\cdot(1-t)$ in the numerator is appropriate when comparing companies with different shares of foreign sources in the financial structure. (Vochozka, 2011)

Companies from Western EU countries have a higher ROE compared to companies from Eastern EU countries, but the latter offered a higher ROA. The inverse of a short-term debt has a high explanatory capacity in the long run. Investment productivity and labour productivity are also instrumental in explaining the variance of inverse of a long-term debt. (Dinca et al., 2017).

The assessment of market concentration is different from the firm perspective, industry perspective and also from the national economy point of view. Shareholders are interested in the firm profitability, since it influences the value of their firm and their investments in the long run. The firm management is responsible for the increasing profits that, in the long run, contribute to maximization of the firm value. (Blažková \& Dvouletý, 2017).

An important feature is the size of a business that we can determine by the number of employees, the size of the turnover or the value of the company's assets. (Camska, 2013, pp.86) In practice, the management still use exclusively the traditional criterial apparatus developed to support the functional (operational) optimization, based on a narrow conception of efficiency, although that does not meet the needs of a consistent process optimization in the contemporary sense (e.g. the criterion of return on costs, return on sales or labour productivity) (Klečka, 2008). The deficiency of this traditional criterial apparatus can be detected especially in insufficient information record of levels and changes of tied-up capital and in the unsystematic, respectively, inconsistent approach to capturing the impact of substitution of inputs and possibly of outputs as well. 
The corporate profitability (often considered in the form of assets return) is also used for the subjective measurement of the financial performance even in cases when a precise computation is not available (Dess \& Robinson, 1984; Pearce \& Robbins, 1987; Hart \& Banbury, 1994; Dawes, 1999; Baer \& Frese, 2003). A reason could be non-availability of the financial performance data because companies are sensitive or unwilling to provide these data and, therefore, the collection of the financial performance data is too complicated. Therefore, it is also widespread to measure the corporate performance through a subjective assessment in surveys. This approach is taken as equivalent to the objective measurement. Not only aforementioned studies have shown a strong positive correlation between the objective and subjective measurement of the financial performance.

Dess \& Robinson (1984) for example investigated the feasibility of measuring the corporate performance in the case of privately owned firms and conglomerates in the absence of objective benchmarks. In the survey, data from 26 US manufacturing companies was collected. The correlation between subjective and objective ROA measurements was 0.611 ( $p<0.01$ ) (Dess \& Robinson, 1984, pp. 268-269). A five-point Likert scale was used for the subjective ROA measurement. Top managers were asked to compare their business with similar ones in their industry and region using the scale mentioned. As in this case, the subjective indicators most often ask respondents to assess their performance to performance of their competitors or an industry sector. It means that the subjective indicators are relative in comparison with the objective measures which are absolute (e.g. profit per one monetary unit of assets).

Other empirical study demonstrating the validity of the convergence of subjective and objective financial performance measures was conducted in 2003. Baer \& Frese (2003) did the research on 47 medium-sized German manufacturing companies. The subjective performance was assessed by the management through the following two questions. The first question was how successful your business corporation is in comparison to others belonging to the same industry branch and having about the same size. The second question was to what extent your business corporation achieved the most important goals. These questions were merged into one index called "Reaching Business Goals" (Cronbach alpha 0.83). The objective measure ROA was used because of its suitability for measuring operational efficiency. It reflects the long-term financial strength of a corporation. The value of the correlation coefficient was equal to 0.41 (Baer \& Frese, 2003, pp. 10).

One of the most current researches focused on the topic of the subjective performance measurement is the research conducted by Sandeep and Harpreet in 2016. The research is based on the data from 171 companies listed on the Indian stock exchange. The strong positive correlation was also reflected in their performance indicators (Sandeep \& Harpreet, 2016).

Majority of studies focusing on examining the impact of different areas on the company performance rely on the subjective performance measurement. Different areas involved could be psychology, management or strategy. The subjective measurement based on the respondents' answers overweighs the measuring based on the verified financial statement data (Wall et al., 2004). The subjective performance measurement is undoubtedly cost-effective because the data collection is processed through questionnaires or interviews. The other reason is that many companies do not have accounting data publicly available or the data published is aggregated in a form which is not appropriate for the planned research and connected analysis. The subjective 
performance measurement is also appropriate if the chosen business corporations come from different industries and therefore they have different goals (or different target values of given indicators) (Fey \& Beamish, 2001).

\section{METHODOLOGY}

All business corporations registered in the public register must present their financial statements at least by the end of the following accounting period in the Czech Republic. The financial statements for the year 2016 are to be published by the end of the year 2017 at the latest if the company's accounting period is identical with the calendar year. This obligation is fully in accordance with the current effective legal rules and norms. Unfortunately, since 2016, changes in the legal rules have brought new reality for users of the financial statements. Micro-and small-sized enterprises (if they are not audited) publish only a shortened version of a balance sheet and explanatory notes. It is not possible to apply a standard approach to the ROA calculation for these enterprises. It is caused by the non-availability of EBIT in any form. EBIT is neither available in the form of operating income nor in the form of profit before interests and taxes. As EBIT at the same time indicates (Earning before Interests and Taxes), or earnings before interest and taxes, or the sum of the profit for the period, tax on extraordinary income and taxes on ordinary income and interest expense, is the only one in the Czech financial statements you will not find right. Or NOPAT (Net Operating Profit after Taxes) is then calculated by simply multiplying x EBIT (1-t), where $t$ is the tax rate on corporate income, which is currently in the Czech Republic $19 \%$ (i.e. $\mathrm{T}=0.19$ ). In the Czech Republic, instead of EBIT and NOPAT, the ROE (or ROE) is also used directly for the accounting period, or for the ordinary activity.

Therefore, our analysis will be focused only on the corporations audited, especially medium and large enterprises. These enterprises have to present an income statement and even a statement of cash flows and of changes in equity. From the accounting point of view, the item of EBIT can be derived as the sum of earnings before taxes and interest charges from the income statement. In financial practice, EBIT is often identified with operating income and, therefore, the item operating income is selected from the income statement directly without any additional modifications. This procedure can be applied in the case of the companies reporting according to Czech accounting practices. The above mentioned data are available and readable. The already discussed exceptions are micro and small sized enterprises which are not audited. On the other hand, a problem may arise for the companies reporting under the IFRS (International Financial Reporting Standards). In accordance with IAS 1, the income statement (or statement of comprehensive income) has a relatively short form because the standards require to publish around ten items. Although one of these ten items is the operating income, the other items do not fulfil our goal to calculate EBIT as the sum of net income, taxes and interest charges. Only net income and, in some cases, tax expenses are also available. A problematic issue is the item of interest charges because the IFRS companies have to publish finance income only, however, the level of the detail published in explanatory notes depends on their assessment.

It is still necessary to comment the item of interest charges because of the enterprises' sample used in the practical part. Interest charges consist especially of interest on loans (if they are not 
capitalized at the acquisition cost of tangible assets), followed by coupon payments from issued bonds for companies reporting according to the Czech accounting rules. In the IFRS concept, the use of interest charges is much wider. There is a requirement to report non-current receivables and non-current liabilities at amortized costs and, therefore, even purchase of inventories with deferred maturity can contain a certain amount of the interest charge. The same issue is observable in the case of finance lease reporting. A certain part of the lease payment is reported as an interest charge. From this point of view, there may be a significant difference in the concept of EBIT if there are companies reporting under the IFRS and companies reporting under Czech accounting rules.

The sample file is the mono-criterial ranking of the 100 most important Czech companies which is compiled according to total sales by CZECH TOP 100, JSC. This company has been operating in the Czech Republic since 1994 and they have been regularly announcing several rankings. These rankings are based on objective criteria and set up in cooperation with leading experts. For each business corporation included in the ranking values, the accounting items were extracted from the financial statements presented in the public business register. The extracted accounting items were for the construction of return on assets (ROA) in two aforementioned forms of nominator discussed. The ratio ROA was computed for the years 2015 and 2016. The first form of the nominator (EBIT) works with the operating income reported directly in the income statement and the second form is based on EBIT as the sum of net income, tax expenses and interest charges. There was not information on the accounting items needed to the described calculation for three companies, therefore, these companies were omitted. Other two companies had available information only for one year so those were also excluded from further analysis, therefore, this analysis worked with 95 companies. 21 out of 95 companies report according to the IFRS and only 18 of these 95 companies are audited by a another audit company than the Big Four (PwC, Deloitte, EY, KPMG). Last but not least, the results were confronted with the capital structure of the analysed company. It was done in order to observe the possible impact of the interest charges within EBIT, respectively the operating income.

\section{RESULTS}

Financial performance was measured each year using the ROA indicator in two forms of calculation. In the first case, the profit was calculated as the operating income gained as a difference of all kinds of operating revenues and expenses. In the second case, the profit EBIT was calculated as the sum of the net profit, tax expenses and interest charges. Subsequently, the ROA indicators were compared and examined whether significant deviations occurred or whether the form of profit calculation is almost irrelevant. If we set an acceptable deviation of ROA at $5 \%$, it will be found that the deviation is less than 5\% for 48 companies in 2016. It means that the calculation distortion is significant for 47 companies in 2016. In the previous year (2015), the deviation was less than $5 \%$ for 49 companies and larger than $5 \%$ for 46 companies. The results may seem more or less the same but there are not always the same companies in each group. Significant distortions can be caused by a very high proportion of finance gains due to finance losses. This overestimates EBIT calculated in the form of net income plus tax expenses and interest charges 
compared to the operating income approach. The second reason is a significantly negative finance income and therefore the operating income is significantly higher than EBIT calculated as the aforementioned sum.

There is a significant distortion of ROA values in 34 companies $(35.8 \%)$ observed in both years. Only in 2016, there is a significant distortion in 13 companies (13.7\%) and 12 companies $(12.6 \%)$ had this significant distortion of ROA values only in 2015. It means that 36 companies $(37.9 \%)$ did not have the distortion of the ROA values caused by a different form of the profit calculation in any period surveyed. These results are displayed by the following figure.

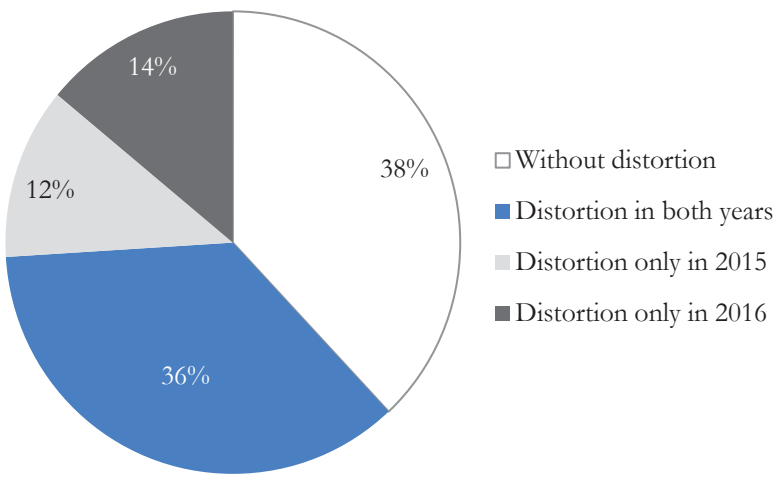

Fig. 1 - ROA Value Differences in 2015 and 2016. Source: own computation

The chosen computation of indicators is not only important for a good benchmark but also for ranking. The construction of the indicator can significantly influence the final order of the companies. The following tables show the ranking in 2015 and 2016. Even the first ten places can significantly differ if there are two ways of the ROA computation used.

Tab. 1 - Ranking Based on ROA in 2016. Source: own computation

\begin{tabular}{|l|l|l|l|l|}
\hline Position & Company & $\begin{array}{l}\text { Operating } \\
\text { Income/ } \\
\text { Assets }\end{array}$ & Company & EBIT/Assets \\
\hline 1 & Continental HT Tyres & $109.56 \%$ & Continental HT Tyres & $109.89 \%$ \\
\hline 2 & $\begin{array}{l}\text { Continental Tyre Pro- } \\
\text { duction }\end{array}$ & $104.69 \%$ & $\begin{array}{l}\text { Continental Tyre Produc- } \\
\text { tion }\end{array}$ & $105.04 \%$ \\
\hline 3 & HENKEL CR & $42.47 \%$ & VEOLIA Czech Republic & $89.25 \%$ \\
\hline 4 & AIRPORT PRAHA & $36.91 \%$ & AT Computers & $72.36 \%$ \\
\hline 5 & Automotive Lighting & $29.25 \%$ & DEK & $54.15 \%$ \\
\hline 6 & Fehrer Bohemia & $26.18 \%$ & HENKEL CR & $42.01 \%$ \\
\hline 7 & $\begin{array}{l}\text { SAINT-GOBAIN } \\
\text { ADFORS CZ }\end{array}$ & $23.11 \%$ & AIRPORT PRAHA & $37.01 \%$ \\
\hline 8 & Alza.cz & $21.94 \%$ & Automotive Lighting & $29.52 \%$ \\
\hline
\end{tabular}




\begin{tabular}{|l|l|l|l|l|}
\hline 9 & Pražská plynárenská & $21.73 \%$ & Fehrer Bohemia & $26.63 \%$ \\
\hline 10 & Philip Morris CR & $21.28 \%$ & $\begin{array}{l}\text { SAINT-GOBAIN AD- } \\
\text { FORS CZ }\end{array}$ & $23.13 \%$ \\
\hline
\end{tabular}

Tab. 2 - Ranking Based on ROA in 2015. Source: own computation

\begin{tabular}{|l|l|l|l|l|}
\hline Position & Company & $\begin{array}{l}\text { Operating } \\
\text { Income/ } \\
\text { Assets }\end{array}$ & Company & EBIT/Assets \\
\hline 1 & Continental HT Tyres & $106.69 \%$ & Continental HT Tyres & $107.25 \%$ \\
\hline 2 & $\begin{array}{l}\text { Continental Tyre Pro- } \\
\text { duction }\end{array}$ & $103.70 \%$ & $\begin{array}{l}\text { Continental Tyre Produc- } \\
\text { tion }\end{array}$ & $104.19 \%$ \\
\hline 3 & AIRORT PRAHA & $31.05 \%$ & AT Computers & $71.05 \%$ \\
\hline 4 & Fehrer Bohemia & $27.05 \%$ & $\begin{array}{l}\text { VEOLIA Czech Re- } \\
\text { public }\end{array}$ & $48.44 \%$ \\
\hline 5 & Alza.cz & $26.28 \%$ & AIRPORT PRAHA & $31.38 \%$ \\
\hline 6 & HENKEL CR & $25.90 \%$ & HENKEL CR & $25.43 \%$ \\
\hline 7 & Automotive Lighting & $24.30 \%$ & Automotive Lighting & $25.20 \%$ \\
\hline 8 & ABB & $22.74 \%$ & Fehrer Bohemia & $25.19 \%$ \\
\hline 9 & Philip Morris CR & $22.68 \%$ & Alza.cz & $24.65 \%$ \\
\hline 10 & O2 Czech Republic & $21.79 \%$ & Philip Morris CR & $22.69 \%$ \\
\hline
\end{tabular}

The ROA indicator evaluates the return on total invested capital and is applicable to measuring aggregate efficiency. We are talking about it as an indication of the past performance of managers. The financial structure in this case is irrelevant, the ability to reproduce capital is assessed. As can be seen from the data above, the companies included in Continental holding (HT Tyres and Tyre Production) held a high level of comparability. They both report according to the Czech accounting rules. The different ranking of the company Airport Praha is not caused by the differences of its own profitability but by the financial results of the other analysed entities. Therefore, it has the better ranking in the case of the operating income used as EBIT than in the case of EBIT as the sum of net income, tax expenses and interest charges.

In the next step, we focused on the impact of indebtedness of the individual companies on the distortion of the ROA values in individual years. The average corporate indebtedness reached $48.64 \%$ in 2016 and $49.74 \%$ in 2015 for the companies of which the distortion rate did not exceed $5 \%$. The companies of which ROAs showed the deviations only in 2016 had the average debt ratio equal to $53.24 \%$ and the companies with the significant imbalance only in 2015 reached the debt ratio of $55.24 \%$. On the other hand, a group of companies with the significant distortions in both years had the debt ratio $59.79 \%$ (in 2016) and $61.46 \%$ (in 2015). It must be emphasized that $68.75 \%$ of companies with the significant deviation in the ROA calculation had the debt ratio larger than $45 \%$.

The calculations above show that the level of indebtedness influences the differences in the calculations using different kinds of profits. From this point of view, it is preferable for the companies with the higher indebtedness to use ranking based on ROA calculated with the nominator as 
the sum of net income, tax expenses and interest charges. On the other hand, in the case of less leveraged companies, both kinds of calculations can be used. To sum it up, this clearly indicates that it is much more appropriate to use the nominator in the form of the sum of net income, tax expenses and interest charges rather than the operating income.

\section{DISCUSSION}

It is evident that it is much more appropriate to use the ROA calculation based on EBIT (the sum of gross profit + interest charges) rather than on the operating income. As can be seen from the text, this recommendation has limitations for the companies reporting under the International Financial Reporting Standards (IFRS). The main reason is that it is often difficult to extract interest charges and sometimes even gross profit (EBT) from the income statement and explanatory notes.

Depending on the profits to be taken into account, it will interpret the result. If the EBIT (the sum of gross profit + interest charges) is included in the formula, then the indicator thus constructed has its justification in the case of a comparison of enterprises with a different tax and interest environment. It can also be stated that when using the operating income in the profitability of the total invested capital, we obtain an item that is comparable to the ROA industry values.

An inappropriate use of the profit can result not only in the false ROA calculation but also in the false economic value added (EVA) identification. The EBIT and operating income are often interpreted as the same basis for further EVA computation. Our results showed that there are many companies in TOP 100 ranking with very different values of these two indicators (the operating income versus sum of net income, tax expenses and interest charges). These differences can reach positive as well as negative values. In this context, determining the right economic value added is really a problematic valuation issue.

The purpose of this contribution is not to analyse the overall quality of the ROA indicator construction but only the impact of the different approaches of the nominator construction. No attention has been paid to the quality of the denominator presented by the total assets. The value of the denominator is influenced by the quality of the input data and the company's approach to the prudence principle application. In the case of the companies reporting under the IFRS, it is also influenced by the proper determination of assets' and liabilities' fair values, respectively their amortized costs.

\section{CONCLUSIONS AND LIMITATIONS}

The results of the conducted research have shown that a different concept of the Return on Asset (ROA) nominator can have a relatively significant impact on the business corporations ranking. As can be seen, the values of only one-third of the companies will not be fundamentally distorted if an analyst uses an operating income instead of the sum of net income, tax expenses and interest charges. On the other hand, two thirds of the companies experienced significant distortions and even 11 of them had opposite trends of the distortions (a positive change based 
on the operating income and a negative change based on earnings before interest and taxes or vice versa).

However, it cannot be said that this distortion occurs more often in the companies reporting under the Czech accounting rules or in the companies reporting under IFRS. The main reasons of these distortions are the financial transactions of the analysed companies which can lead to significant differences between the operating income and earnings before interest and taxes.

The results of the paper prove that the level of indebtedness influences the difference in the ROA calculations when different kinds of profit are used. In the case of the companies with a higher indebtedness (above $45 \%$ of interest bearing debts), it is more appropriate to compare the ROA indicators based on the nominator containing earnings before interest and taxes (EBIT). This nominator has also a high comparison power in the case of the companies with a lower indebtedness.

It must be emphasized that this is probably the first contribution of this kind conducted in the Czech environment but probably also in the countries of Central and Eastern Europe. However, the limitation of the current approach exists as the authors selected the companies included in TOP 100 ranking and they did not focus on one or more specific industry sectors. This would help them achieve higher data comparability. For this reason, the authors chose a ranking approach to the results evaluation.

\section{References}

1. Baer, M. \& Frese, M. (2003). Innovation is not enough: Climates for initiative and psychological safety, process innovations and firm performance. Journal of Organizational Behavior, 24 (1), 45-68. http://dx.doi.org/10.1002/job.179.

2. Blažková, I. \& Dvouletý, O. (2017). Drivers of ROE and ROA in the Czech Food Processing Industry in the Context of Market Concentration. Agris on-line Papers in Economics and Informatics, 9 (3), 3-14.

3. Čamská, D. (2013). Basic Characteristics of Enterprises in Insolvency. Conference: International Scientific Conference on Hradec Economic Days 2013 - Economic Development and Management, Hradec Kralové, Czech Republic, Feb 19-20, 2013, 83-88.

4. Čamská, D. (2016). Accuracy of Models Predicting Corporate Bankruptcy in a Selected Industry Branch. Ekonomický časopis, 64 (4), 353-366. http://dx.doi.org/ 10.1080/00014788. 2007.9663313.

5. Dawes, J. (1999). The Relationship between Subjective and Objective Company Performance Measures in Market Orientation Research: Further Empirical Evidence. Marketing Bulletin, 10 (1), 65-75.

6. Dess G. G. \& Robinson R.B. Jr. (1984). Measuring organizational performance in the absence of objective measures: The case of the privately-held firm and conglomerate business unit. Strategic Management Journal, 5(1), 265-273.

7. Dinca, M. S, Barbuta-Misu, N., Madalene, M., Dinca, G. et al. (2017). Integrated Analysis of EU Construction Companies' Financial Performances. Journal of Construction Engineering and Management, 143 (6), 1-17. http://dx.doi.org/10.1061/(ASCE)CO.1943-7862.0001287. 
8. Fey, C. F. \& Beamish, P. W. (2001). Organizational climate similarity and performance: international joint ventures in Russia. Organization Studies, 22 (5), http://dx.doi.org/853-882. $10.1177 / 0170840601225005$.

9. Hart S. \& Banbury, C. (1994). How strategy-making processes can make a difference. Strategic Management Journal, 15 (4), 251-269. http://dx.doi.org/ 10.1002/smj.4250150402.

10. Klečka, J. (2008). Produktivita a její měření - nové přístupy. Ekonomika a management [online], 2 (1), 16-29.

11. Klečka, J. \& Čamská, D. (2015). Corporate value productivity based on Interantional and National Accounting Standards. Conference: The 9th International Days of Statistics and Economics. Sep 10-12, 2015, 781-789.

12. Kotulič, R. (2014). Vybrané metodické prístupy k pyramídovému rozkladu rentability majetku pre potreby riadenia firmy. Scientific Papers of the University of Pardubice. 21 (32), 53-61.

13. Pearce J. A. II, Robbins D. K. \& Robinson, R. B. Jr. (1987). The impact of grand strategy and planning formality on financial performance. Strategic Management Journal, 8 (2), 125-134. http://dx.doi.org/10.1002/smj.4250080204.

14. Růčková. P., (2011). Finanční analýra, metódy, ukazatele, vyǔ̌ití v praxi. 4. aktulizované vydání. Praha: Grada Publishing.

15. Sandeep, V. \& Harpreet, S. B. (2016). Are subjective business performance measures justified. International Journal of Productivity and Performance Management, 65 (5), 603-621. http:// dx.doi.org/10.1108/IJPPM-12-2014-0196.

16. Wall, T. D., Michie, J., Patterson, M., Wood, S. J. et al. (2004). On the validity of subjective measures of company performance. Personnel Psychology, 57 (1), 95-118. http://dx.doi. $\operatorname{org} / 10.1111 /$ j.1744-6570.2004.tb02485.x.

17. Vochodzka, M. (2011). Metódy komplexního honodcení podniku. Praha: Grada Publishing.

\section{Contact information}

prof. Ing. Jirú Stroubal, Ph.D.

Czech Technical University in Prague

MIAS School of Business and Interdisciplinary Studies

Department of Economic Studies

Czech Republic

E-mail:jiri.stroubal@cvut.cz.

Ing. Petra Stamfestová, Ph.D.

University of Economics Prague

Faculty of Business Administration

Department of Strategy

Caech Republic

E-mail:petra.stamfestova@vse.cz. doc. Ing. Aleksandr Ključnikov, Ph.D.

Paneuropean University

Faculty of Economics and Business

Slovakia

E-mail:kliuchnikov@gmail.com

Ing. Zuzana Vincúrová, PhD.

Paneuropean University

Faculty of Economics and Business

Slovakia

E-mai:ruðana.vincurova@paneurouni.com 